\title{
Growth, Shedding and Food Intake in Captive Eunectes murinus (Linnaeus, 1758) (Serpentes: Boidae)
}

\author{
Crecimiento, Muda y Consumo de Alimento en Cautiverio de la Eunectes murinus (Linnaeus, 1758) \\ (Serpentes: Boidae)
}

"Rita de Cássia Lamonica; "*Henrique Abrahão-Charles; *"Mariana Fiuza de Castro Loguercio \& *"Oscar Rocha-Barbosa

LAMONICA, R. C.; ABRAHÃO-CHARLES, H.; LOGUERCIO, M. F. C. \& ROCHA-BARBOSA, O. Growth, shedding and food intake in captive Eunectes murinus (Linnaeus, 1758) (Serpentes: Boidae). Int. J. Morphol., 25(1):103-108, 2007.

SUMMARY: The anaconda Eunectes murinus (Linnaeus, 1758) inhabits large hydrographic basins in tropical America and figures among the world's largest snakes, attaining a length of $12 \mathrm{~m}$. This study analyzed the growth of three female anaconda siblings, with records from their birth in captivity up to around 14 months of age. The snakes were kept in a controlled environment with constant temperature and data related to biometry, feeding and skin shedding were recorded. At the end of these 445 days, the siblings had grown on average 2.6 times their initial length and increased their initial weight by $3830.10 \mathrm{~g}$, incorporating about $43.5 \%$ of total food ingested to their body mass. They showed a total of 0.69 skin sheddings per month in that period, and did not exhibit significant differences in shedding intervals, nor in body growth (weight and length), when compared among themselves. Food was refused at times, coinciding with the days that preceded the ecdyses. Sheddings do not seem to be explained by feeding or growth, which suggests a relation to other endogenous factors. A more detailed study of this species is needed to better understand its growth to the adult phase and its hormonal levels during growth.

KEY WORDS: Anaconda; Biometry; litter; Ecdysis; Ontogeny.

\section{INTRODUCTION}

The snake Eunectes murinus (Linnaeus, 1758) inhabits large hydrographic basins in tropical America, from Colombia to Brazil, between $\sim 10^{\circ} \mathrm{N}$ and $26^{\circ} \mathrm{S}$ (Murphy \& Henderson, 1997). It is a large snake that may attain a length of $12 \mathrm{~m}$, portrayed as an object of fear and fascination for riverside populations (Amaral, 1978).

The anaconda is a constrictor snake which usually seeks a point of anchorage on land, e.g. coiling its tail around tree trunks, to strangle its victims (Amaral; Henderson et al., 1995). Essentially aquatic, it moves on land to look for prey or for an appropriate site to give birth (Beebe, 1946; Cunha \& Nascimento, 1978). Active both by day and by night, it lives on the water edge or submerged in rivers and lakes (Argôlo, 2004), where it feeds on mammals (Cunha \& Nascimento; Duellman, 1989; Martins \& Oliveira, 1998), birds (Cunha \& Nascimento; Martins \& Oliveira), fishes (Beebe), anurans and lizards (Martins \& Oliveira) and crocodilians (Amaral). A viviparous snake, it produces litters of 20-40 hatchlings, although litters of up to 82 individuals have been recorded (Belluomini et al., 1959).
An anaconda female, which was received by the Vital Brazil Institute's serpentary as a five year-old adult in 1976, and was kept in captivity without ever having contact with any males of the species, gave birth in August 2002 to 23 female individuals and 20 atresic eggs. Among the hatchlings, 20 were stillborn and only three were born alive. The present work aims to obtain data on this species and on its growth, monitoring the development of these three surviving youngsters from their birth to a little over one year of age.

\section{MATERIAL AND METHOD}

Snake specimens and captivity. Three female anacondas were studied. They were born in captivity and identified as $7895,76 \mathrm{FA}$ and $31 \mathrm{BO}$ via subcutaneous microchips applied to the third segment of the animals' bodies (latero-posterior). The snakes were kept in the Vital Brazil Institute's Serpentary, in Niterói Municipality, Rio de Janeiro State, Brazil, housed singly in three $60 \times 40 \times 30 \mathrm{~cm}$ aquaria

* Laboratório de Herpetologia, Departamento de Biologia Animal, Instituto de Biologia, Universidade Federal Rural do Rio de Janeiro, Rodovia BR-465 km 07, Seropédica, RJ, 23890-000, Brasil. ritalamonica@ufrrj.br

** Laboratório de Zoologia de Vertebrados (Tetrapoda), Departamento de Zoologia/UERJ, IBRAG, Universidade do Estado do Rio de Janeiro, Rua São Francisco Xavier, 524, Maracanã, 20550-013, Rio de Janeiro - Brasil. obarbosa@uerj.br 
containing $\sim 1 / 3$ of their volume in water, in a acclimatized room with a constant temperature of $26^{\circ} \mathrm{C}$ and natural photoperiod, from August 2002 to November 2003.

During the same period the behavior of these snakes' mother was also monitored. The latter, identified with microchip number $876 \mathrm{E}$, was kept at the same institute, in an outdoor vivarium enclosed with meshed wire, not climatized, $28 \mathrm{~m}^{2}$ in diameter and with a $2 \times 4 \times 1-\mathrm{m}$ pond. Data referring to other anacondas' litters were taken from the literature (Belluomini et al., 1959; 1976/77), in order to compare with the snakes in the present study.

Feeding.The hatchlings were fed weekly with mice from the same institution's biotherium, since their $12^{\text {th }}$ day of age, right after the first skin shedding. Each of the three siblings was always offered the same number of mice with the same average weight. As the snakes grew, the number of mice offered gradually increased.

As the snakes did not always accept all the mice offered to them, food consumption varied among the siblings. The percentage of food intake was calculated as the ratio of relative weight to consumed food. The mother was fed once a month with adult rabbits weighing $\sim 2 \mathrm{~kg}$ each.

Biometric data. Weight and total length of body, head, tail and snout-vent length of the hatchlings were recorded every two weeks from Aug. 2002 to Nov. 2003. Animals were weighed on an electronic digital scale to the nearest $0.5 \mathrm{~g}$. Length measurements were taken by pinning each snake onto a $70 \times 50 \mathrm{~cm}, 20 \mathrm{~mm}$ thick polypropylene foam sheet of 33 density with a $60 \times 40 \mathrm{~cm}$ transparent acrylic plate, and then drawing a contour of the snake from snout tip to tail tip along the spinal column on the plate with a felt-tip pen. A piece of string was then placed over the contour and measured. These data were not taken for the adult female $876 \mathrm{E}$.

Ecdyses. The dates of skin shedding were recorded throughout the period, not only for the hatchlings but for the mother as well. However, only the siblings were measured and weighed after sheddings.

Rate of ecdysis per month was calculated dividing the number of ecdyses per month by total number of snakes (Panizzutti et al., 2001).

Statistical analyses. All statistical analyses were performed using SYSTAT 11.

Averages of head, tail, total length and snout-vent length measurements of the three young taken at birth were compared by a t-test with the means for 29 female neonates belonging to two different litters recorded by Belluomini et al. (1959).

Two-weekly values of relative growth of head, snoutvent, tail and total lengths, relative weight and feeding among the three siblings were analyzed with ANOVA. We also compared relative growth of total length and relative weight increase data after each change among the four hatchlings (three siblings from the present study and one female analyzed by Belluomini et al., 1976/77) by ANOVA, followed by Bonferroni's post hoc test.

To compare intervals between sheddings, an ANOVA including the three siblings, the adult female and the young from Belluomini et al. (1976/77) was performed. We later compared the same data for the categories hatchlings versus adults.

\section{RESULTS}

At the time of birth the three individuals 7895, 76FA and 31B0 weighed between 175.8 - 187.5g and measured between $705-725 \mathrm{~mm}$ total length. When compared to the litters recorded by Belluomini et al. (1959), they differed significantly in head length and tail length $(p<0.05)$, but not in total body length or SVL $(p>0.05)$.

During the study's 445 days, the three hatchlings displayed an increase of $3830.10 \pm 450.28 \mathrm{~g}$ in body mass, about $42.49 \%$ of all the food consumed, and a growth of $1150.00 \pm 48.22 \mathrm{~mm}$ in total body length, which corresponds to an increase of $2.60 \pm 0.05$ times over their initial total length. Table I features the initial and final values of the three siblings for each of the biometric parameters studied. Growth (in total body length) and weight increase curves are shown in Fig. 1.

Table I. Descriptive analysis of biometric data (initial and final) of anaconda hatchlings up to the $14^{\text {th }}$ month of life.

\begin{tabular}{lcc}
\cline { 2 - 3 } & INITIAL & FINAL \\
\hline Total body length $(\mathrm{mm})$ & $626 \pm 13.89$ & $1574 \pm 79.92$ \\
Head length $(\mathrm{mm})$ & $35.67 \pm 0.58$ & $60 \pm 2.00$ \\
Tail length $(\mathrm{mm})$ & $90.67 \pm 5.13$ & $261,666 \pm 7.64$ \\
Total length $(\mathrm{mm})$ & $717 \pm 10.41$ & $1867 \pm 56.86$ \\
Weight $(\mathrm{g})$ & $183 \pm 6.46$ & $4013 \pm 443.93$ \\
\hline
\end{tabular}

There were no significant differences among the three hatchlings studied as to food consumption increase, relative weight and relative length of head, tail, SVL and total relative 
growth $(p>0.05)$. The amount of food consumption at the end of the litters' first year of life is presented in Table II, as well as the food intake percentage for the same period.

Table II. Food consumption and intake at the end of the litter's first year. Food intake is calculated as the ratio of final weight minus initial weight to total food consumption.

\begin{tabular}{ccc}
\hline $\begin{array}{c}\text { Food } \\
\text { consumption }(\mathrm{g})\end{array}$ & $\begin{array}{c}\text { Food } \\
\text { intake }(\%)\end{array}$ & References \\
\hline 4646 & 49.53 & Belluomini et al., 197677 \\
$9011 \pm 951.98$ & $42.49 \pm 1.21$ & This study \\
$(8177-10048)$ & $(41.09-43.26)$ & \\
\hline
\end{tabular}

When we compare the weight and total length increase data for the three anacondas and the one described by Belluomini et al. (1976/77), we note a significant difference between groups (relative total length: $\mathrm{F} 3,102=5.765, p<0.05$; relative weight: $\mathrm{F} 3,102=7.020, p<0.001)$. However, Bonferroni's post hoc test revealed that a significant difference within the group was found only when comparing the snake in Belluomini et al. (1976/77) with the others, for both parameters. Monthly weight, total length, food consumption and shedding rates are indicated in Table III.

Table III. Monthly weight, total length, food consumption and shedding rates.

\begin{tabular}{lcc}
\cline { 2 - 3 } & This study $(\mathbf{n}=\mathbf{3})$ & Belluomini et al . $(\mathbf{n = 1})$ \\
\hline Weight $(\mathrm{g})$ & $273.58 \pm 32.16$ & 171.4 \\
Total length $(\mathrm{mm})$ & $82.14 \pm 3.44$ & 58.57 \\
Food consumption $(\mathrm{g})$ & $643.62 \pm 68.00$ & 331.8 \\
Food intake (\%) & $43.08 \pm 16.38$ & 49.53 \\
Shedding $(\mathrm{n})$ & $0.69 \pm 0.04$ & 0.57 \\
\hline
\end{tabular}

During the study period, from Aug. 2002 to Nov. 2003, a total of 10 skin sheddings occurred in snakes 76FA and 31B0. Anaconda number 7895 only shedded 9 times. Fig. 1 presents shedding in relation to absolute weight $(\mathrm{A})$ and to absolute total length (B). Average frequency was 1.45 \pm 0.09 sheddings/month, with 0.69 sheddings/month/anaconda (Table III). Data referring to weights and relative growth after sheddings and the respective shedding intervals can be seen in Fig. 2.

The adult anaconda (876E) shedded only 7 times in the study period. However, when the intervals in days between sheddings for the mother, the litter and the snake described by Belluomini et al. (1976/77) were compared, no significant difference was found $(p>0.05)$. When the group was split into adults and hatchlings, no significant difference was seen either, but the $\mathrm{p}$ value was very close to the significance level $(\mathrm{F} 1,48=3.703, p=0.06)$.

In the present study, it was not possible to obtain data on the sexual maturity of the litter observed, since the observation period was a little over one year.
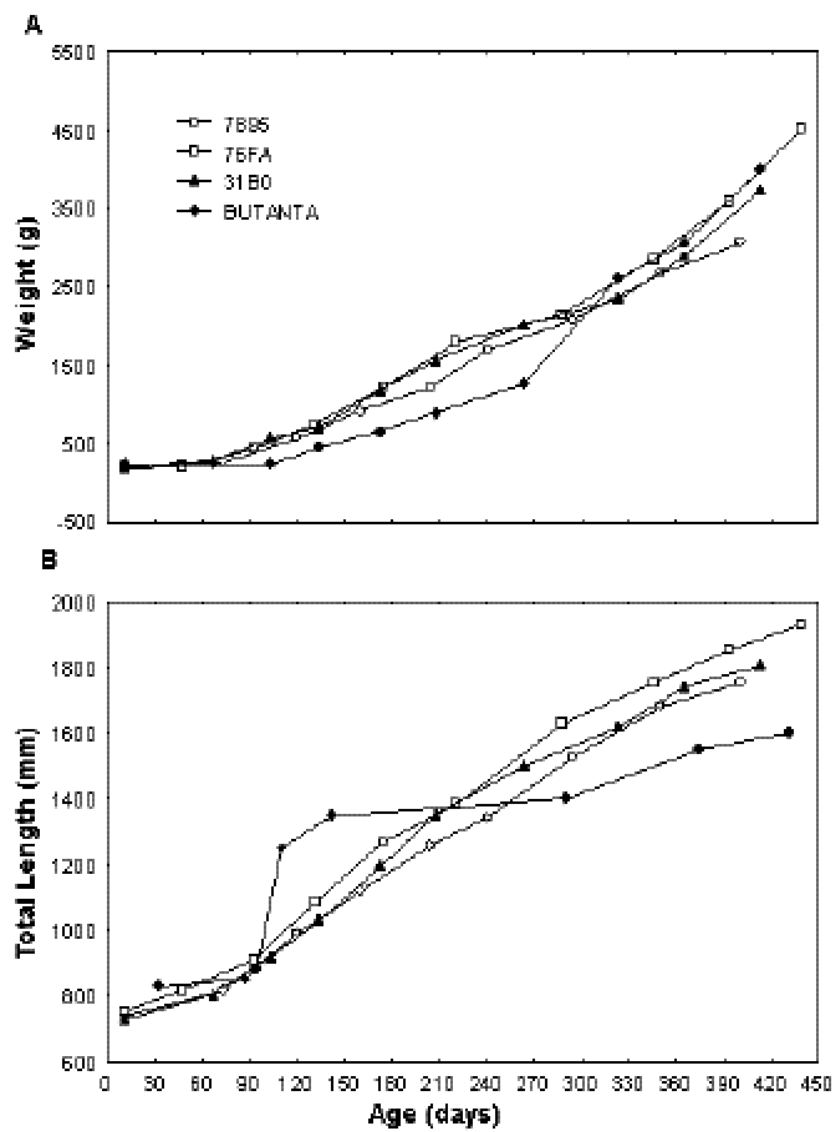

Fig. 1. Relation between age and (A) weight and (B) total length. Symbols indicate time of sheddings.

\section{DISCUSSION}

Despite the fact that many studies have investigated the feeding habits and growth rates of different snake species (e.g. Gibbons, 1972; Barnard et al., 1979; Barnett \& Schwaner, 1985; Gregory \& Prelypchan, 1994; Forsman, 1996; Scudder-Davis \& Burghardt, 1996; Cundall \& Greene, 2000; Schuett et al., 2005), knowledge on the growth of litters is still scarce, especially in large snakes such as Eunectes murinus. Very large snakes are almost entirely tropical, probably because of thermal constraints in temperate-zone climates (Shine \& Madsen, 1996). Given the paucity of detailed ecological data from tropical areas worldwide, the 

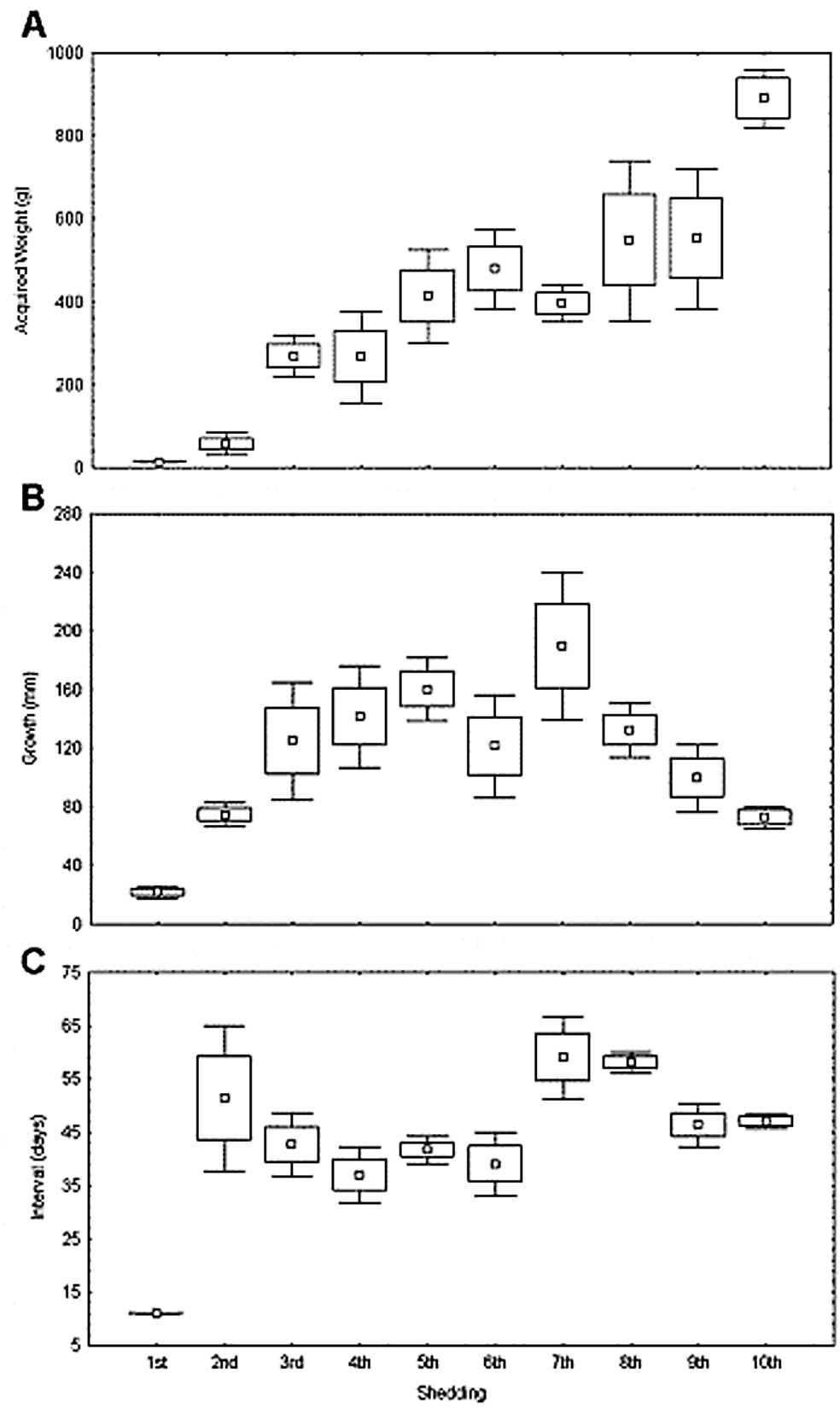

Fig. 2. Relative weight (A) and relative total growth (B) after sheddings and intervals between sheddings (C). Tenth shedding corresponds only to young 76FA and $31 \mathrm{~B} 0$.

lack of studies on giant snakes is quite understandable (Shine et al., 1998). The present study is thus significant for providing additional information on the ecdysis and biometry of this species, considered the largest of Brazilian snakes.

Differences were observed as to head and tail biometry between the litter in the present study and the litters of Belluomini et al. (1959) measured shortly after birth. A possible explanation for the difference between studies is that Belluomini's snakes were stillborn and fixated. The movement of live snakes, for instance, may have led to this divergence in values.

The three young snakes, during successive feeding events, reacted differently to the food offered. Mice were many times rejected, especially in periods before skin shedding, as mentioned by King \& Turmo (1997). This irregular eating habit is common in snakes, even captive ones (Smith, 1976; Barnard et al.). In spite of this, no significant differences were seen among siblings in any of the biometric parameters analyzed.

Snakes of the family Elapidae in Indonesia, in their first year of life, display a SVL growth rate between 0.3-0.5 mm/day, while others from Malaysia grow 0.32-1.0 $\mathrm{mm} /$ day (Masunaga \& Ota, 2003). Our study

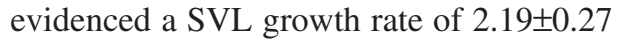
$\mathrm{mm}$ per day for the hatchlings. Shine (1978) reports a 2-3.2 times increase in total length and 6-18 times weight increase for Australian snakes one year after birth. The siblings studied herein had a total length and weight increase of 2.60 and 21.93 times, respectively. This shows that the growth and weight proportions do not vary that much for different species, even from different families.

The difference found between the litter studied and the young female studied by Belluomini et al. (1976/77) as to relative growth and weight, indicated by Bonferroni's post hoc test, suggests that these two parameters are independent from the interval between sheddings, which, in turn, did not differ between hatchlings and mother. However, the $p$-value very close to the level of significance found when comparing the shedding intervals between the adult female and the youngsters may be related to the latter's growth phase.

Saint-Girons \& Duguy (1976) and Saint-Girons (1980) observed that European vipers have regular shedding cycles, on average, twice a year. Mosmann (2001) presents the frequency of ecdyses, for snakes in general, as two to four times a year. Panizzutti et al. demonstrated on rattlesnakes a shedding/month/snake rate of up to 1.8 higher than that seen in anacondas (0.69). 
The fact that the five snakes (one adult, its three offspring and the young studied by Belluomini et al., 1976/ 77) showed no difference in shedding intervals, but differ as to relative growth and weight, may be an indication that endogenous hormonal factors are responsible for the determination of shedding frequency. This can be concluded because the climatic conditions to which the snakes were subjected were not equal, the three siblings being kept in a acclimatized room while the adult female and Belluomini's snake were kept at room temperature.

According to Hildebrand (2003), sheddings take place several times a year, influenced by humidity and hormones. Our study seems to corroborate the hypothesis of an endogenous control, possibly hormonal, for the ecdysis cycle. However, variations in environmental factors, such as humidity and temperature, do not appear to influence the intervals between sheddings in the species Eunectes murinus.
We therefore suggest that intra or interspecific shedding rate differences are related to the snakes' biology, and not to each individual's growth rate as discussed by Mosmann.

ACKNOWLEDGEMENTS. We thank the Vital Brazil Institute for this research opportunity, for making available the snakes and all physical resources needed for this study, notably the Head of Sector, Dr Aníbal Rafael Melgarejo; FAPERJ for financial support and the CAPES Fellowship, Programa de Pós-Graduação em Biologia Animal -UFRRJ. Special thanks are due to our friends Aline Cruz, Martilene Cortes, Michelle Barbosa de Senna, Hanriet Alves, Renata Tatissuia and other workers who helped with cleaning activities, maintenance of the aquaria and data collection. We would also like to thank Humberto Moura-Neto for his help with the English translation of our manuscript.

LAMONICA, R. C.; ABRAHÃO-CHARLES, H.; LOGUERCIO, M. F. C. \& ROCHA-BARBOSA, O. Crecimiento, muda y consumo de alimento en cautiverio de la Eunectes murinus (Linnaeus, 1758) (Serpentes: Boidae). Int. J. Morphol., 25(1):103-108, 2007.

RESUMEN: La anaconda Eunectes murinus (Linnaeus, 1758) se encuentra en una ampia área hidrográfica de América tropical y figura entre las más grandes serpientes del mundo, alcanzando una longitud de 12 metros. Este estudio analizó el crecimiento de tres anacondas hembras hermanas, con registros de su nacimiento en cautiverio hasta alrededor de 14 meses de edad. Las serpientes fueron mantenidas en un medio controlado con temperatura constante y se obtuvieron registros relacionados con su biometría, alimentación y mudas de piel.Al final de 445 días, las hermanas crecieron en promedio 2,6 veces su longitud inicial e incrementaron su peso inicial en 3810,1 g, incorporando a su masa corporal alrededor de 43,5\% del alimento ingerido. Ellas tuvieron un total de 0,69 mudas de piel por mes en ese periodo y no hubo diferencias significativas en los intervalos de mudas, ni en el crecimiento corporal (peso y longitud), cuando comparadas entre ellas. La comida, a veces, fue rechazada coincidiendo con los días que precedían al cambio de piel. Las mudas de piel parecen no tener relación con la alimentación o crecimiento, lo cual sugiere que puede deberse a otros factores endógenos. Es necesario un estudio más detallado de esta especie para comprender mejor su crecimiento en la fase adulta y sus niveles hormonales durante el crecimiento.

PALABRAS CLAVE: Anaconda; Biometría; Muda; Ontogenia.

\section{REFERENCES}

Amaral, A. Serpentes do Brasil. Iconografia Colorida. $2^{\mathrm{a}}$ ed. Melhoramentos/EDUSP, São Paulo, 1978.

Argôlo, A. J. S. As serpentes dos cacauais do sudeste da Bahia. Editus, Ilhéus, Bahia, 2004.

Barnard, S. M.; Hollinger, T. G. \& Romaine, T. A. Growth and food consumption in the corn snake, Elaphe guttata guttata (Serpentes Colubridae). Copeia, 4:739-41, 1979.

Barnett, B. \& Schwaner, T. D. Growth in captive born tiger snakes (Notechis alter serventyi) from Chappell Island: implications for field and laboratory studies. Trans. $R$. Soc. S. Aust. 109: 31-6, 1985.

Beebe, W. Field notes on the snakes of Kartabo, British Guiana, and Caripito, Venezuela. Zoologica, 31:11-52, 1946.

Belluomini, H. E.; Maranhão Nina, A. F. \& Hoge, A. R. Contribuição à biologia do gênero Eunectes Wagler, 1830. (Serp. Boidae) Estudo de seis ninhadas de sucuris. Mem. Inst. Butantan, 29:165-74, 1959.

Belluomini, H. E.; Veinert, T.; Dissmann, F.; Hoge, A. R. \& Penha, A. M. Notas biológicas a respeito do gênero Eunectes Wagler, 1830 "sucuris". (Serpentes: Boinae). Mem. Inst. Butantan, 40/41:79-115, 1976/77.

Cundall, D. \& Greene, H. W. Feeding in snakes. In Feeding: form, function and evolution in tetrapod vertebrates. Schwenk, K. (Ed.). San Diego, CA: Academic Press, 2000. pp. 293-333. 
Cunha, O. R. \& Nascimento, F. P. Ofídios da Amazônia X. As cobras da região leste do Pará. Publ. Avul. Mus. Par. Emílio Goeldi, 1:7-166, 1978.

Duellman, W. E. Tropical herpetofaunal communities: Patterns of community structure in neotropical rainforest. In: M. L. Harmelin-V. \& F.Boorliére (Eds.). Vertebrates in Complex Tropical Systems, Springer-Verlag, New York, 1989. pp. 61-88.

Forsman, A. An experimental test for food effects on head size allometry in juvenile snakes. Evolution, 50: 253642, 1996.

Gibbons, J. W. Reproduction, growth and sexual dimorphism in the canebrake rattlesnake (Crotalus havidus atricaudatus). Copeia, 2:222-6, 1972.

Gregory, P. T. \& Prelypchan, C. J. Analysis of variance of first-year growth in captive garter snakes (Thamnophis elegans) by family and sex. J. Zool. (Lond.) 232: 31322, 1994.

King, R. B. \& Turmo, J. The effects of ecdysis on feeding frequency and behavior of the commongarter snake (Thamnophis sirtalis). J. Herpetol., 31:310-2, 1997.

Henderson, R. W.; Micucci, T. W. P.; Puorto, G. \& Bourgeois, W. Ecological correlates and patterns in the distribution of neotropical boines (Serpentes: Boidae): a preliminary assessment. Herpetol. Nat. History, 3(1):15-27, 1995.

Hildebrand, M. Analysis of Vertebrate Structure. $5^{\text {th }}$ ed. New York, John Wiley and Sons, 2003.

Martins, M. \& Oliveira, M. E. Natural history of snakes in forest of the Manaus region, central Amazonian, Brazil. Herpetol. Nat. History, 6:78-150, 1998.

Masunaga, G. \& Ota, H. Growth and reproduction of the sea snake, Emydocephalus ijimae, in the Central Ryukyus, Japan: a mark and recapture study. Zool. Sci., 20: 461$70,2003$.

Mosmann, M. N. Guia das Principais Serpentes do Mundo. 1v. Canoas, ULBRA, 2001.

Murphy, J. C. \& Henderson, R. W. Tales of giant snakes a historical natural history of Anacondas and Pythons. Krieger Publishing Company, Malabar, FL, 1997.

Panizzutti, M. H. M.; Oliveira, M. M.; Barbosa, J. L.; Cavalcanti, P. L. X. \& Rocha-Barbosa, O. Evaluation of a balanced fresh past diet for maintenance of captive neotropical rattlesnakes used for venom production. JAVMA, 218(6):912-4, 2001.

Saint-Girons, H. \& Duguy, R. Écologie et position systématique de Vipera seoanei Lataste, 1879. Bull. Soc. Zool. Fr., 101:325-39, 1976.

Saint-Girons, H. Le cycle des mues chez les vipères européennes. Bull. Soc. Zool. Fr., 105:551-9, 1980.

Scudder-Davis, R. M. \& Burghardt, G. M. Ontogenetic changes in growth efficiency in laboratory-reared water snakes of the genus Nerodia. The Snake, 27:75-84, 1996.

Schuett, G. W.; Hardy Sr, D. L.; Earley, R. L. \& Greene, H. W. Does prey size induce head skeleton phenotypic plasticity during early ontogeny in the snake Boa constrictor? J. Zool., 267:363-9, 2005.

Shine, R. Growth rates and sexual maturation in six species of Australian elapid snakes. Herpetologica, 34:73-9, 1978.

Shine, R. \& Madsen, T. Is thermoregulation unimportant for most reptiles? An example using water phytons (Liasis fuscus) in tropical Australia. Physiol. Zool., 69:252-69, 1996.

Shine, R.; Harlow, P. S.; Keogh, J. S. \& Boeadi. The influence of sex and body size on food habits of a giant tropical snake, Phython reticulatus. Func. Ecol., 12:248-58, 1998.

Simth, G. C. Ecological energetics of three species of ectothermic vertebrates. Ecology, 57(2):252-64, 1976.

Correspondence to:

Prof. Dr. Oscar Rocha-Barbosa

Universidade do Estado do Rio de Janeiro

Laboratório de Zoologia de Vertebrados (Tetrapoda)

PHLC sl. 513b/515b

Departamento de Zoologia, IBRAG

Rua São Francisco Xavier, 524 Maracanã

20550-013

Rio de Janeiro, RJ - BRASIL

Email: obarbosa@uerj.br

Received: 18-12-2006

Accepted: 16-01-2007 